\title{
Centennial-scale compound-specific hydrogen isotope record of Pleistocene-Holocene climate transition from southern New England
}

\section{Citation}

Hou, Juzhi, Yongsong Huang, W. Wyatt Oswald, David R. Foster, and Bryan Shuman. 2007. Centennial-Scale Compound-Specific Hydrogen Isotope Record of Pleistocene-Holocene Climate Transition from Southern New England. Geophysical Research Letters 34, no. 19. doi:10.1029/2007gl030303.

\section{Published Version}

doi:10.1029/2007gl030303

\section{Permanent link}

http://nrs.harvard.edu/urn-3:HUL.InstRepos:30674684

\section{Terms of Use}

This article was downloaded from Harvard University's DASH repository, and is made available under the terms and conditions applicable to Other Posted Material, as set forth at http:// nrs.harvard.edu/urn-3:HUL.InstRepos:dash.current.terms-of-use\#LAA

\section{Share Your Story}

The Harvard community has made this article openly available.

Please share how this access benefits you. Submit a story.

Accessibility 


\title{
Centennial-scale compound-specific hydrogen isotope record of Pleistocene-Holocene climate transition from southern New England
}

\author{
Juzhi Hou, ${ }^{1}$ Yongsong Huang, ${ }^{1}$ W. Wyatt Oswald, ${ }^{2}$ David R. Foster, ${ }^{2}$ and Bryan Shuman ${ }^{3}$ \\ Received 6 April 2007; revised 8 August 2007; accepted 5 September 2007; published 9 October 2007.
}

[1] Northeastern North America experienced major climate shifts during the Pleistocene-Holocene transition. However, there have been no high-resolution isotopic records of climate change from this region. Here, we present a centennial-scale record of climate change during the transition based on $\mathrm{D} / \mathrm{H}$ ratios of behenic acid $\left(\mathrm{C}_{22} n\right.$ acid) or $\delta \mathrm{D}_{\mathrm{BA}}$ from a sediment core in Blood Pond, Massachusetts. Surface calibrations from a transect of 19 lakes in eastern North America show that $\delta \mathrm{D}_{\mathrm{BA}}$ values track mean annual atmospheric temperature variations. The abrupt climate events observed in Blood Pond records show remarkable similarity with Greenland ice core $\delta^{18} \mathrm{O}$ records during the Pleistocene. During the early Holocene, the northeastern North America $\delta \mathrm{D}_{\mathrm{BA}}$ record was more variable than Greenland, possibly due to the close proximity of the Laurentide ice sheet, and impact of freshwater outbursts as the ice sheet rapidly retreated. Citation: Hou, J., Y. Huang, W. W. Oswald, D. R. Foster, and B. Shuman (2007), Centennialscale compound-specific hydrogen isotope record of PleistoceneHolocene climate transition from southern New England, Geophys. Res. Lett., 34, L19706, doi:10.1029/2007GL030303.

\section{Introduction}

[2] The Pleistocene-Holocene transition is characterized by abrupt climatic fluctuations around North Atlantic Ocean [e.g., Stuiver et al., 1995; Hughen et al., 1996]. However, the spatial variations in the timing, amplitude, and phasing of the abrupt events are less understood on the adjacent continents. This is particularly true for the northeastern North America where the driving forces for climate were particularly complex, comprising a combination of changes in North Atlantic sea surface temperature, Laurentide ice sheet (LIS) extent, atmospheric composition, and insolation [e.g., Webb et al., 1993]. Centennial-scale quantitative records from the northeastern North America are thus extremely important for better understanding marineterrestrial-atmosphere-cryosphere connections and regional climatic responses.

[3] Existing paleoclimate records from the northeastern North America are mainly based on paleoecological approaches, such as assemblages of pollen [e.g., Peteet et al., 1990; Webb et al., 1993; Shuman et al., 2002] and Chironomidae (midge) [e.g., Cwynar and Spear, 2001;

\footnotetext{
${ }^{1}$ Department of Geological Sciences, Brown University, Providence, Rhode Island, USA.

${ }^{2}$ Harvard Forest, Harvard University, Petersham, Massachusetts, USA.

${ }^{3}$ Department of Geography, University of Minnesota, Minneapolis, Minnesota, USA.
}

Copyright 2007 by the American Geophysical Union. 0094-8276/07/2007GL030303\$05.00
Walker et al., 1997] from lake sediments. However, the possibility of transient vegetation responses to short-term, small-magnitude climate variations [e.g., Davis and Botkin, 1985], and the non-analogue conditions for Chironomidae [e.g., Kurek et al., 2004] could increase the difficulty of using pollen and Chironomidae data to assess abrupt $(<$ centennial-scale) climate variability.

[4] Compound-specific hydrogen isotope analyses of aquatic lipids in sediments [e.g., Sauer et al., 2001; Huang et al., 2002, 2004; Dawson et al., 2004] offer a new way to quantify past climate variations. The technique is especially useful for regions like northeastern North America where the lake sediments lack carbonate deposit. Organic compounds produced by algae and macrophytes track lake water isotopic variations [e.g., Huang et al., 2002, 2004; Hou et al., 2006; Sauer et al., 2001], which in regions of high precipitation-evaporation (P-E) ratio, mimic precipitation isotopic variations. For example, the low resolution record of $\mathrm{D} / \mathrm{H}$ ratios of behenic acid $\left(\mathrm{C}_{22} n\right.$-acid $)$ or $\delta \mathrm{D}_{\mathrm{BA}}$ tracks general climate variation for the past $16,000 \mathrm{yr}$ at BloodPond [Hou et al., 2006]. The objectives of this study are: (1) to establish a transfer function between $\delta \mathrm{D}_{\mathrm{BA}}$ and surface air temperature; (2) to quantify the temperature variations of the abrupt climate events during the Pleistocene-Holocene transition; and (3) to integrate with other isotopic records and pollen data to probe the mechanisms of abrupt climate events in northeastern North America.

\section{Samples and Methods}

[5] Blood Pond $\left(42.081^{\circ} \mathrm{N}, 71.961^{\circ} \mathrm{W}, 212.1 \mathrm{~m}\right.$ above sea level) is a kettle pond located in Massachusetts (Figure 1). The lake is mainly recharged by ground water and precipitation, with a southerly overflow outlet. The sediment core was collected in 2001, and samples for isotope analyses were selected at $6 \mathrm{~cm}$ intervals. Chronology for the core is provided by AMS- ${ }^{14} \mathrm{C}$ dating of bulk organic matter which were converted to calendar years before present (cal yr B.P.) using OxCal 3.9 [Hou et al., 2006]. The preparation of the samples and the measurement of hydrogen isotopes have been described previously [Hou et al., 2006]. Briefly, lipids were extracted from freeze-dried sediment using an Accelerated Solvent Extractor 200 (Dionex). Acid fractions were isolated, methylated, and purified. A HP 6890 GC interfaced to a Finnigan Delta ${ }^{+}$XL stable isotope spectrometer through a high-temperature pyrolysis reactor was used for hydrogen isotopic analysis. The precession $(1 \sigma)$ of triplicate analyses was $< \pm 2 \%$. The accuracy was routinely checked by measuring laboratory isotopic standards every six measurements. Temperature changes of precipitation were also reconstructed based on pollen assemblages in 


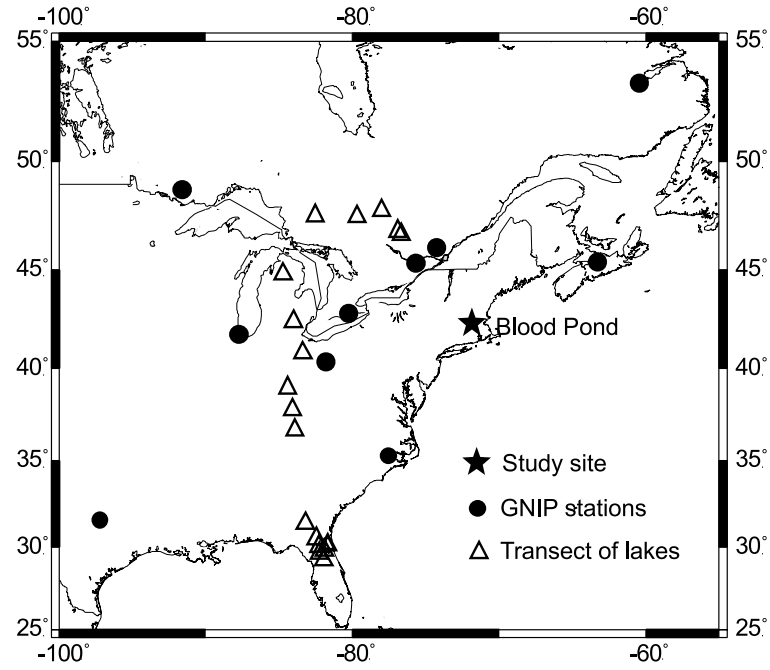

Figure 1. Map showing the location of Blood Pond (star), the GNIP stations (circles), and lakes along north-south transect (solid triangles).

the same sediment core using the modern analog technique described by Webb et al. [2003].

\section{Results and Discussions}

\subsection{Relationship Between $\delta \mathrm{D}_{\mathrm{BA}}$ and Surface Air Temperature}

[6] $\mathrm{D} / \mathrm{H}$ ratios of $\mathrm{C}_{22} n$-acid $\left(\delta \mathrm{D}_{\mathrm{BA}}\right)$ from lake surface sediment track lake water $\mathrm{D} / \mathrm{H}$ ratios along lake transects in eastern North America [Hou et al., 2006]. However, the relationship between the $\delta \mathrm{D}_{\mathrm{BA}}$ values and surface air temperature $(\mathrm{T})$ has not been established. Here, we establish the relationship between $\delta \mathrm{D}_{\mathrm{BA}}$ and $\mathrm{T}$ along the $\mathrm{N}-\mathrm{S}$ transect (Figure 1; see Huang et al. [2004] for details of the transect) across a temperature gradient $\left(2\right.$ to $\left.23^{\circ} \mathrm{C}\right)$ in eastern North America (Figure 2, left),

$$
\delta \mathrm{D}_{\mathrm{BA}}=4.3 \mathrm{~T}-208.4, \mathrm{R}^{2}=0.96, \mathrm{p}<0.001
$$

[7] Based on this relationship, a $1{ }^{\circ} \mathrm{C}$ change in $\mathrm{T}$ corresponds to $\sim 4.3 \pm 0.2 \%$ variation in $\delta \mathrm{D}_{\mathrm{BA}}$. To validate this relationship, we determined the relationship between $\mathrm{T}$ and precipitation $\delta \mathrm{D}$ value $\left(\delta \mathrm{D}_{\mathrm{P}}\right)$ using the data from Global Network of Isotopes in Precipitation (GNIP) stations in eastern North America (Figure 1) [Rozanski et al., 1993]. The $\delta \mathrm{D}_{\mathrm{P}}$ data show a linear correlation with $\mathrm{T}$ (Figure 2, right),

$$
\delta \mathrm{D}_{\mathrm{P}}=5.2 \mathrm{~T}-113.0, \mathrm{R}^{2}=0.97, \mathrm{p}<0.001
$$

This suggests that $1{ }^{\circ} \mathrm{C}$ change in $\mathrm{T}$ corresponds to a change of $\sim 5.2 \pm 0.2 \%$ in $\delta \mathrm{D}_{\mathrm{P}}$. The apparent isotopic fractionation $(\alpha)$ for $\mathrm{C}_{22} n$-acid relative to lake water is constant along the transect [Hou et al., 2006]:

$$
\alpha=0.8681=\frac{1000+\delta D_{B A}}{1000+\delta D_{P}}
$$

or

$$
0.8681\left(1000+\delta \mathrm{D}_{\mathrm{P}}\right)=1000+\delta \mathrm{D}_{\mathrm{BA}}
$$

Substituting (1) and (2) into (4), we obtain $4.5( \pm 0.2) \mathrm{T}+$ $770 \approx 4.3( \pm 0.2) \mathrm{T}+792$. This suggests that the relationship between $\delta \mathrm{D}_{\mathrm{BA}}$ and $\mathrm{T}$ is consistent with that between $\delta \mathrm{D}_{\mathrm{P}}$ and $\mathrm{T}$, when the $\mathrm{D} / \mathrm{H}$ fractionation during the biosynthesis of behenic acid is taken into consideration.

\section{2. $\delta \mathrm{D}_{\mathrm{BA}}$ Fluctuations and Climatic Implications}

[8] $\delta \mathrm{D}_{\mathrm{BA}}$ values from Blood Pond sediments show pronounced variations during the Pleistocene-Holocene transition (Figure 3, also see auxiliary material). ${ }^{1} \mathrm{D} / \mathrm{H}$ ratios increased by $\sim 20 \%$ between 16 and $14.8 \mathrm{ka}$. The Bølling and Allerød warm periods were indicated by higher $\delta \mathrm{D}$ values at $14.8-14.4 \mathrm{ka}$ and $14.2-13.7 \mathrm{ka}$, which were separated by one sample with low $\delta \mathrm{D}_{\mathrm{BA}}$ value. The most significant $\delta \mathrm{D}$ variations were observed at the beginning and the end of Younger Dryas chronozone (YD). YD was indicated by lower $\delta \mathrm{D}_{\mathrm{BA}}$ values with some fluctuations. The lowest $\delta \mathrm{D}_{\mathrm{BA}}$ value occurred around $12.3 \mathrm{ka}$. The $\delta \mathrm{D}_{\mathrm{BA}}$ records show similar fluctuations with $\delta^{18} \mathrm{O}$ records from GISP2 ice core and Crawford Lake during late Pleistocene (Figure 3). During early Holocene, $\delta \mathrm{D}$ values showed more frequent fluctuations with smaller amplitudes, occurred at $10.9,10.6,10.3$ to $10.1,9.7,9.3$ and $8.9 \mathrm{ka}$, respectively. Although $\delta \mathrm{D}_{\mathrm{BA}}$ values in the transect show strong correlation with $\mathrm{T}$ (Figure 2, left), $\delta \mathrm{D}_{\mathrm{BA}}$ variations with small magnitude $(<10 \%)$ and defined by a single sample could be attributed to other factors in addition to temperature, such as $\mathrm{P}-\mathrm{E}$ ratios, hydrological balance of lake water, seasonal shifts in precipitation. We will focus on major downcore $\delta \mathrm{D}_{\mathrm{BA}}$ shifts to avoid over-interpreting the data as temperature changes.

\subsubsection{Late Pleistocene (16-13.2 ka)}

[9] Surface air temperature increased by $\sim 5^{\circ} \mathrm{C}$ between 16 and $14.8 \mathrm{ka}$. The warmest period of the Late Pleistocene occurred between 14.8 and $14.4 \mathrm{ka}$, coinciding with the Bølling period (B). The Allerød period (A) is about $2{ }^{\circ} \mathrm{C}$ cooler than Bølling. Warmth during the $\mathrm{B}-\mathrm{A}$ periods inferred from the $\delta \mathrm{D}_{\mathrm{BA}}$ data matches the warming pattern found in Greenland. Three short cold periods defined by single samples show similar temperature amplitude as those from GISP2 $\delta^{18} \mathrm{O}$ (Oldest Dryas, Older Dryas, and Intra Allerød cold period (IACP), Figure 3), although variation in $\mathrm{P} / \mathrm{E}$ ratios and seasonal changes in precipitation may affect the $\delta \mathrm{D}_{\mathrm{BA}}$ changes. The onset of the Bølling period, and the step-change during B-A periods at Blood Pond appear to lead the GISP2 temperature changes by about 100 to 300 years. This may not reflect a real difference in phasing, as the chronological inaccuracies in Blood Pond records (100-350 year uncertainties, Figure 3 ) and/or the reservoir effect in Blood Pond could readily lead to observed chronological differences.

\subsubsection{Younger Dryas Chronozone (13.2-11.6 ka)}

[10] The most significant temperature shifts in the record occurred at the beginning and end of the YD. The beginning of YD $(13.2-13 \mathrm{ka})$ is marked by $\sim 5.6^{\circ} \mathrm{C}$ decline in temperature. Temperatures fluctuated during the YD, with

Auxiliary materials are available at ftp://ftp.agu.org/apend/gl/ $2007 \mathrm{gl} 1030303$. 

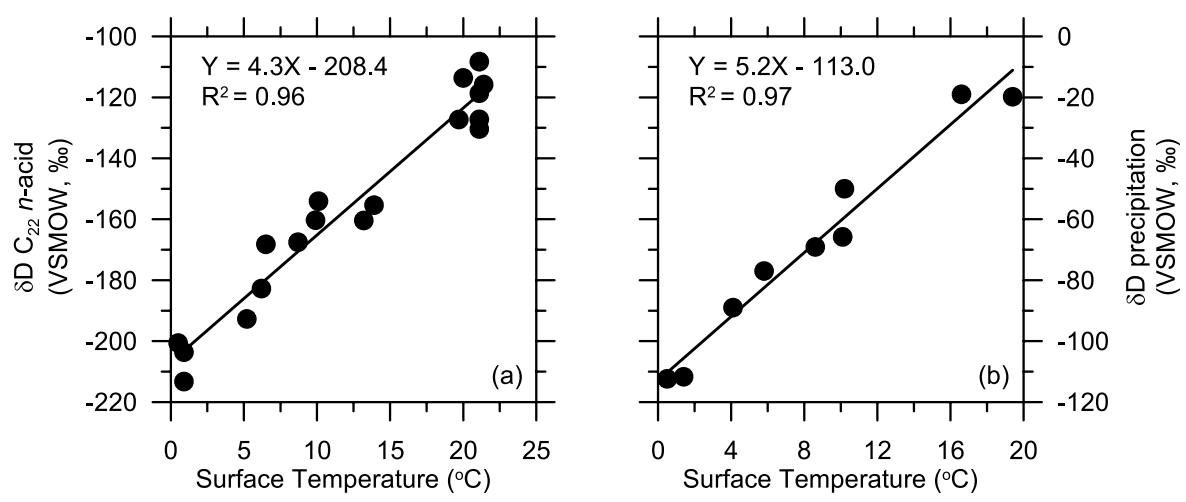

Figure 2. Correlation between (left) $\mathrm{D} / \mathrm{H}$ ratios of behenic acid $\left(\mathrm{C}_{22} n\right.$-acid) or $\delta \mathrm{D}_{\mathrm{BA}}$ and surface air temperature $(\mathrm{T})$ along the north-south transect in eastern North America, and (right) mean annual $\delta \mathrm{D}$ of precipitation $\left(\delta \mathrm{D}_{\mathrm{P}}\right)$ and surface air temperature (T) for GNIP stations in eastern North America (1961-1987, data from Rozanski et al. [1993]).

the lowest temperature occurring at $\sim 12.3 \mathrm{ka}$. The YD ended abruptly at $11.6 \mathrm{ka}, \sim 5.4^{\circ} \mathrm{C}$ increase in less than 200 years. The $\delta \mathrm{D}_{\mathrm{BA}}$-inferred temperature variations from Blood Pond can be compared with carbonate $\delta^{18} \mathrm{O}$ variation from Crawford Lake in Ontario [Yu and Eicher, 1998] (Figure 3), White Lake in New Jersey [Yu, 2006], and with opal $\delta^{18} \mathrm{O}$ change from Linsley Lake in Connecticut [Shemesh and Peteet, 1998]. The $\delta^{18} \mathrm{O}$-inferred temperature variation in Crawford Lake and White Lake was $\sim 6$ and $8^{\circ} \mathrm{C}$ [Yu and Eicher, 1998; Yu, 2006]. The opal $\delta^{18} \mathrm{O}-$ inferred temperature change in Connecticut was $\sim 6^{\circ} \mathrm{C}$ [Shemesh and Peteet, 1998]. Temperature changes during the YD have also been estimated using Chironomidae assemblages from lakes in the White Mountains of New Hampshire [Cwynar and Spear, 2001] and from pollen data in New England [e.g., Huang et al., 2002] and New York

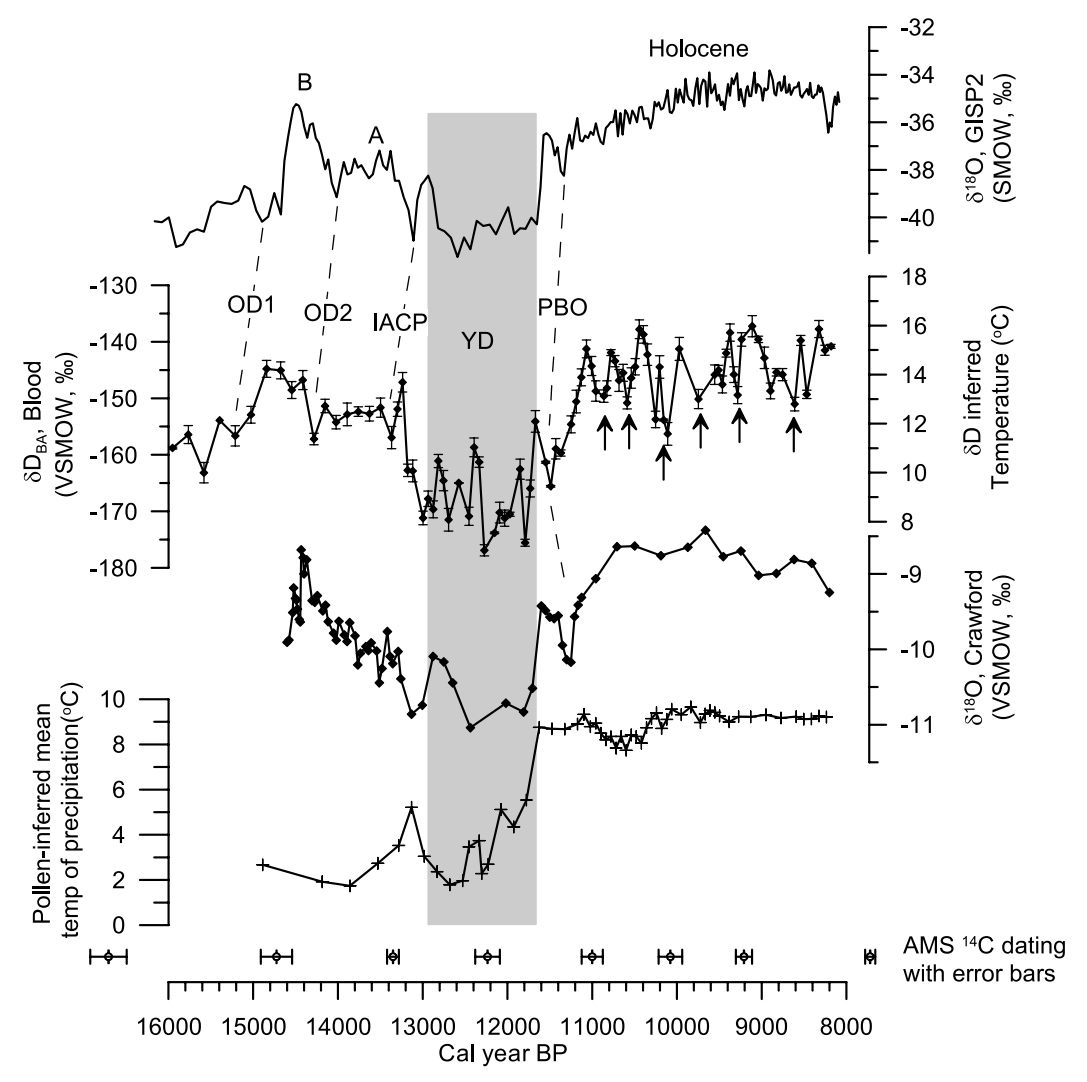

Figure 3. $\delta \mathrm{D}_{\mathrm{BA}}$ record and pollen-inferred temperature from Blood Pond during the transition from late Pleistocene to Holocene in comparison with $\delta^{18} \mathrm{O}$ data from Greenland Ice Sheet Project 2 (GISP2), and carbonate $\delta^{18} \mathrm{O}$ from Crawford Lake. The abbreviations indicate the corresponding periods: OD1, Oldest Dryas; OD2, Older Dryas; IACP, Intra-Allerød cold period; YD, Younger Dryas; PBO, Pre-Boreal oscillation; B, Bølling; A, Allerød. The arrows beside the $\delta \mathrm{D}_{\mathrm{BA}}$ curve indicate the freshwater outburst from proglacial lakes. Calibrated ages from accelerator mass spectrometry radiocarbon (AMS ${ }^{14} \mathrm{C}$ ) dating with errors are shown. 
[Webb et al., 2003]. The observed temperature decline in the Chironomidae records was $\sim 5$ to $6^{\circ} \mathrm{C}$ [Cwynar and Spear, 2001]; pollen data show $\sim 8^{\circ} \mathrm{C}$ increase in January temperatures and $\sim 4^{\circ} \mathrm{C}$ increase in July temperatures after the YD [Huang et al., 2002; Webb et al., 2003]. The Blood Pond pollen data were used to infer a $3^{\circ} \mathrm{C}$ decline in the mean temperature of precipitation at the beginning of the $\mathrm{YD}$, and an $8^{\circ} \mathrm{C}$ increase at the end of YD (Figure 3).

\subsubsection{Early Holocene (11.6-8 ka)}

[11] A series of abrupt temperature excursions is evident in the early Holocene interval of the record. A temperature decrease of $\sim 3^{\circ} \mathrm{C}$ follows a warming trend at the end of the YD (just before $11.5 \mathrm{ka}$ ). This cooling may represent the Preboreal Oscillation (PBO). After $11.5 \mathrm{ka}$, temperature increased $\sim 6^{\circ} \mathrm{C}$ in $\sim 400$ years, which is also observed in the $\delta^{18} \mathrm{O}$ record from Crawford Lake [Yu and Eicher, 1998], but was not seen in pollen-based climate reconstructions from northeastern North America and in the Greenland ice core records (Figure 3). In addition to $\mathrm{PBO}$, some other potential cold periods are also revealed by the lower $\delta \mathrm{D}_{\mathrm{BA}}$ record, around on $10.9,10.6,10.3$ to $10.1,9.7,9.3$ and $8.9 \mathrm{ka}$.

\subsection{Comparison of Pollen and Isotope-Based Temperature Reconstructions}

[12] Mean temperature of annual precipitation inferred from pollen assemblages in the same sediment core using the modern analog method [Webb et al., 2003] show similar variations as inferred from the $\delta \mathrm{D}_{\mathrm{BA}}$ especially for the $\mathrm{YD}$ (Figure 3, note the absolute values of pollen and $\delta \mathrm{D}$ inferred temperatures differ due to independent calibrations). However, there are discrepancies between pollen and $\delta \mathrm{D}_{\mathrm{BA}}$ inferred temperatures. For example, between 15 and $13.5 \mathrm{ka}$, pollen data suggest lower temperature than inferred by $\delta \mathrm{D}_{\mathrm{BA}}$ record. Despite similar sampling resolution, multiple fluctuations of $\delta \mathrm{D}_{\mathrm{BA}}$ during the early Holocene are not observed in the pollen data (Figure 3). The discrepancies may result from misrepresentation of dry conditions as cool conditions by the pollen method, and/or the misrepresentation of dry conditions as warm conditions by the isotopic data (both $\delta \mathrm{D}_{\mathrm{BA}}$ from Blood Pond and carbonate $\delta^{18} \mathrm{O}$ from Crawford Lake). Although the northeastern North America is known for positive P-E ratio, which favors relatively small evaporative enrichment, a radical decrease in the P-E balance could enrich $\mathrm{D} / \mathrm{H}$ ratios of lake water. The low lake level between 15 to $13.5 \mathrm{ka}$ [Shuman et al., 2001] may have enriched lake water $\mathrm{D} / \mathrm{H}$ ratios, causing higher $\delta \mathrm{D}_{\mathrm{BA}}$ values. Alternatively, the close proximity to the Laurentide ice sheet during the pre-YD period could alter the moisture source for precipitation, the precipitation seasonality. Local hydrologic factors could alter the residence time of the lake, the balance of groundwater and surface runoff into the lake, and/or the source of groundwater. More studies are needed to reconcile these discrepancies.

\subsection{Overall Patterns of the Abrupt Climate Change in Northeastern North America}

[13] Comparison of the Blood Pond $\delta \mathrm{D}_{\mathrm{BA}}$ data with the GISP2 $\delta^{18} \mathrm{O}$ record reveals similarity in the number and timing of abrupt climate events during the late Pleistocene (Figure 3). Five Greenland cold regimes have been centered around 14.8 (OD1), 14 (OD2), 13.2 (IACP), 12.3 (YD,
12.9-11.6) and 11.4 ka (PBO). Consistent with this, five cold periods are found in Blood Pond. The $\delta^{18} \mathrm{O}$ data from Crawford Lake, Ontario and White Lake, New Jersey also suggest similar climate shifts [Yu and Eicher, 1998; Yu, 2006]. The similarity in the sequence of the climate events implies that repeated reversals during the late Pleistocene in the North Atlantic region is related to a common cause i.e., the changes in thermohaline circulation due to freshwater outbursts [Clark et al., 2001].

[14] During the early Holocene, the linkage of the climate regimes of Greenland and northeastern North America appears to have weakened. There is more variability in the northeastern North America than in the Greenland, and the amplitude of the temperature increase after the $\mathrm{PBO}$ is larger in the northeastern North America records $\left(\sim 6^{\circ} \mathrm{C}\right)$ than in Greenland $\left(\sim 2^{\circ} \mathrm{C}\right)$. The GISP2 $\delta^{18} \mathrm{O}$ data show a more gradual temperature increase until $10 \mathrm{ka}$ (Figure 3 ). Melting of the Laurentide ice sheet (LIS) from 12 to $10 \mathrm{ka}$ accelerated due to the elevated summer insolation in North Hemisphere [COHMAP Members, 1988]. The combination of the high insolation and rapidly retreating LIS may have resulted in a faster warming trend on the North American continent than in Greenland after the YD. Additionally, Blood Pond $\delta \mathrm{D}_{\mathrm{BA}}$ values show six negative isotopic shifts, indicating cold events lasting decades to centuries which are not observed in the Greenland record (Figure 3). The timing of these events is close to the freshwater outbursts of relatively smaller magnitudes from Lake Agassiz, centered at $\sim 10.6,10.4,10.3,10.0,9.5$, and 9.2 ka [e.g., Clark et al., 2001; Teller et al., 2002]. The cold freshwater may influence northeastern North America by cooling coastal waters and the local atmosphere, rather than strongly affecting the thermohaline circulation and altering the climate around the North Atlantic basin, as has been suggested for the YD, PBO and $8.2 \mathrm{ka}$ events [e.g., Clark et al., 2001; Alley and Agustsdottir, 2005]. Therefore, the effect of these smaller freshwater outbursts on the Greenland ice sheet was minimal.

\section{Conclusions}

[15] $\mathrm{D} / \mathrm{H}$ ratios of behenic acid $\left(\mathrm{C}_{22} n\right.$-acid $)$ or $\delta \mathrm{D}_{\mathrm{BA}}$ are strongly correlated to the surface air temperature $(\mathrm{T})$ along a 19-lake transect in eastern North America. The temperature dependence of $\delta \mathrm{D}_{\mathrm{BA}}$ is $4.3 \% /{ }^{\circ} \mathrm{C}$. This is consistent with the relationship between isotopic precipitation and $\mathrm{T}$ in eastern North America $\left(5.2 \%{ }^{\circ} \mathrm{C}\right)$, when the isotopic fractionation of behenic acid $(\alpha=0.8681)$ is taken into consideration. In Blood Pond, isotope-inferred temperatures closely track pollen-inferred temperatures. Therefore, the general features of the $\delta \mathrm{D}_{\mathrm{BA}}$ are robust, although some disagreement between pollen and isotopic values demonstrates the potential for different responses of lake water $\delta \mathrm{D}$ values and terrestrial vegetation to climate change. Abrupt climate events observed in the GISP2 ice core during the Late Pleistocene are also detected in $\delta \mathrm{D}_{\mathrm{BA}}$ record from Blood Pond. This implies that climate change in both Greenland and northeastern North America during this time was related to a common cause, namely the changes in thermohaline circulation in North Atlantic Ocean due to freshwater outbursts. During the early Holocene, climate in northeastern North America showed greater variability than in Greenland, 
possibly reflecting multiple climate forcing factors in northeastern North America versus a more uniform control by solar insolation above Greenland ice sheet. Multiple episodes of fresh water outbursts from Lake Agassiz may have induced a number of abrupt climate cooling events in northeastern North America during the early Holocene, each lasting several decades.

[16] Acknowledgments. We thank two anonymous reviewers for their helpful comments on the early version of this paper. This work was supported by grants from the National Science Foundation (NSF 0318050, 0318123, 0402383) to Y. Huang.

\section{References}

Alley, R. B., and A. M. Agustsdottir (2005), The 8k event: Cause and consequences of a major Holocene abrupt climate change, Quat. Sci. Rev., 24, 1123-1149.

Clark, P. U., S. J. Marshall, G. K. C. Clarke, S. W. Hostetler, J. M. Licciardi, and J. T. Teller (2001), Freshwater forcing of abrupt climate change during the last glaciation, Science, 293, 283-287.

COHMAP Members (1988), Climatic changes of the last 18,000 years: Observations and model simulations, Science, 241, 1043-1052.

Cwynar, L. C., and R. W. Spear (2001), Late glacial climate change in the White Mountains of New Hampshire, Quat. Sci. Rev., 20, 1265-1274.

Davis, M. B., and D. B. Botkin (1985), Sensitivity of cool-temperate forests and their fossil pollen record to rapid temperature-change, Quat. Res., 23, $327-340$.

Dawson, D., K. Grice, S. X. Wang, R. Alexander, and J. Radke (2004), Stable hydrogen isotopic composition of hydrocarbons in torbanites (Late Carboniferous to Late Permian) deposited under various climatic conditions, Org. Geochem., 35, 189-197.

Hou, J., Y. Huang, Y. Wang, B. Shuman, W. W. Oswald, E. Faison, and D. R. Foster (2006), Postglacial climate reconstruction based on compound-specific D/H ratios of fatty acids from Blood Pond, New England, Geochem. Geophys. Geosyst., 7, Q03008, doi:10.1029/2005GC001076.

Huang, Y., B. Shuman, Y. Wang, and T. Webb III (2002), Hydrogen isotope ratios of palmitic acid in lacustrine sediments record late Quaternary climate variations, Geology, 30, 1103-1106.

Huang, Y., B. Shuman, Y. Wang, and T. Webb III (2004), Hydrogen isotope ratios of individual lipids in lake sediments as novel tracers of climatic and environmental change: A surface sediment test, J. Paleolimnol., 31, $363-375$.

Hughen, K. A., J. T. Overpeck, L. C. Peterson, and S. Trumbore (1996), Rapid climate changes in the tropical Atlantic region during the last deglaciation, Nature, 380(6569), 51-54.

Kurek, J., L. C. Cwynar, and R. W. Spear (2004), The 8200 cal yr BP cooling event in eastern North America and the utility of midge analysis for Holocene temperature reconstructions, Quat. Sci. Rev., 23, 627-639.
Peteet, D. M., J. S. Vogel, D. E. Nelson, J. R. Southon, R. J. Nickmann, and L. E. Heusser (1990), Younger Dryas climatic reversal in northeastern USA: AMS ages for an old problem, Quat. Res., 33, 219-230.

Rozanski, K., L. Araguás-Araguás, and R. Gonfiantini (1993), Isotopic patterns in modern global precipitation, in Climate Change in Continental Isotopic Records, Geophys. Monogr. Ser., vol. 78, edited by P. K. Swart et al., pp. 1-36, AGU, Washington, D. C.

Sauer, P. E., T. I. Eglinton, J. M. Hayes, A. Schimmelmann, and A. L. Sessions (2001), Compound-specific D/H ratios of lipid biomarkers from sediments as a proxy for environmental and climatic conditions, Geochim. Cosmochim. Acta, 65, 213-222.

Shemesh, A., and D. Peteet (1998), Oxygen isotopes in fresh water biogenic opal: Northeastern US Allerød-Younger Dryas temperature shift, Geophys. Res. Lett., 25, 1935-1938.

Shuman, B., L. Bravo, J. Kaye, J. A. Lynch, P. Newby, and T. Webb III (2001), Late Quaternary water-level variations and vegetation history at Crooked Pond, Southeastern Massachusetts, Quat. Res., 56, 401-410.

Shuman, B., P. J. Bartlein, N. Logar, P. Newby, and T. Webb III (2002), Parallel climate and vegetation responses to the early Holocene collapse of the Laurentide Ice Sheet, Quat. Sci. Rev., 21, 1793-1805.

Stuiver, M., P. M. Grootes, and T. F. Braziunas (1995), The GISP2 $\delta^{18} \mathrm{O}$ climate record of the past 16,500 years and the role of sun, ocean, and volcanoes, Quat. Res., 44, 341-354.

Teller, J. T., D. W. Leverington, and J. D. Mann (2002), Freshwater outbursts to the oceans from glacial Lake Agassiz and their role in climate change during the last deglaciation, Quat. Sci. Rev., 21, 879-887.

Walker, I. R., A. J. Levesque, L. C. Cwynar, and A. F. Lotter (1997), An expanded surface-water palaeotemperature inference model for use with fossil midges from eastern Canada, J. Paleolimnol., 18, 165-178.

Webb, T., III, P. J. Bartlein, S. P. Harrison, and W. G. Spaulding (1993), Vegetation, lake levels, and climate in Eastern North America for the past 18,000 years, in Global Climates Since the Last Glacial Maximum, edited by H. E. Wright Jr. et al., pp. 415 -467, Univ. of Minn. Press, Minneapolis.

Webb, T., III, B. Shuman, P. Leduc, P. Newby, and N. Miller (2003), Late Quaternary climate history of western New York State, Bull. Buffalo Soc. Nat. Sci., 37, 11-17.

Yu, Z. (2006), Rapid response of forested vegetation to multiple climatic oscillations during the last deglaciation in the northeastern United States, Quat. Res., 67, 297-303.

Yu, Z., and U. Eicher (1998), Abrupt climate oscillations during the last deglaciation in central North America, Science, 282, 2235-2238.

D. R. Foster and W. W. Oswald, Harvard Forest, Harvard University, Petersham, MA 03166, USA.

J. Hou and Y. Huang, Department of Geological Sciences, Brown University, 324 Brook Street, Providence, RI 02912, USA. (yongsong huang@brown.edu)

B. Shuman, Department of Geography, University of Minnesota, 414 Social Science Building, Minneapolis, MN 55455, USA. 